\title{
10 The relationship between university culture and climate and research scientists' spin-off intentions
}

\author{
Annelore Huyghe \& Mirjam Knockaert
}

Annelore Huyghe
University of Ghent
Tweekerkenstraat 2
9000 Gent, Belgium
Email: annelore.huyghe@ ugent.be
Mirjam Knockaert
University of Ghent
Tweekerkenstraat 2
9000 Gent, Belgium
\& University of Oslo
Centre for Entrepreneurship
Norway
Email: mirjam.knockaert@ugent.be

\begin{abstract}
Over the past decades, universities have increasingly become involved in entrepreneurial activities. Despite efforts to embrace their 'third mission', universities still demonstrate great heterogeneity in terms of their involvement in academic entrepreneurship. This chapter adopts an institutional perspective to understand how organizational characteristics affect research scientists' entrepreneurial intentions. We study the impact of university culture and climate on entrepreneurial intentions, thereby specifically focusing on intentions to spin off a company. Using a sample of 437 research scientists from Swedish and German universities, our results reveal that the extent to which universities articulate entrepreneurship as a fundamental element of their mission fosters research scientists' spin-off intentions. Furthermore, the presence of university role models positively affects research scientists' propensity to engage in entrepreneurial activities, both directly and indirectly through entrepreneurial self-efficacy. Finally, research scientists working at universities which explicitly reward people for 'third mission' related output show higher levels of spin-off intentions. This study has implications for
\end{abstract}


both academics and practitioners, including university managers and policy makers.

A revised version of this article was accepted for publication in The Journal of Technology Transfer; DOI 10.1007/s10961-014-9333-3.

\section{INTRODUCTION}

Universities do not only engage in research and teaching, but are increasingly active in the commercialization of research results, or their so-called 'third mission' related to entrepreneurship and economic development (Etzkowitz 2003; Rasmussen et al. 2006). This entrepreneurial tendency is inspired by decreasing university budgets and pressure from policy makers who view the commercialization of research as a key driver of national competitiveness (Ambos et al. 2008). 'Third stream' entrepreneurial activities go beyond the traditional, scientific dissemination mechanisms, such as publications (Van Looy et al. 2011), and include university spin-offs, patenting and licensing activities, contract research and consulting (Wright et al. 2008).

As a result of the institutional transformation and universities' growing interest to fulfill their 'third mission', the academic literature has devoted considerable attention to academic entrepreneurship. We refer to Rothaermel et al. (2007), Markman et al. (2008) and Djokovic and Souitaris (2008) for excellent reviews of the literature. In summary, the academic entrepreneurship literature includes studies at macro-level (studying the role of government and industry), meso-level (focusing on the university and the technology transfer office) and micro-level (studying firms and individual entrepreneurs) (Djokovic and Souitaris 2008). Only recently, scholars have started to explore research scientists' entrepreneurial intentions (e.g., Mosey et al. 2012; Prodan and Drnovsek 2010). Entrepreneurial intentions are considered the single best predictor of entrepreneurial behavior (Bird 1988; Fishbein and Ajzen 1975) and have been widely studied as outcome variable in diverse contexts (Krueger et al. 2000; Souitaris et al. 2007).

Studying entrepreneurial intentions in an academic context is important given the presence of entrepreneurial potential in scientific knowledge (Obschonka et al. 2012). Academic research has been a crucial ingredient for the development of new products and processes (Mansfield 1998) and about 70\% of inventions require further involvement by the research scientist in order to be successfully commercialized (Jensen and Thursby 2001). Academic entrepreneurship provides a critical contribution of research scientists to the national economy and society (Ping 1980) and is often considered crucial for competitive advantage (OECD 2003). Nevertheless, it is recognized that commercializing research results is difficult. At the heart of the problem is the inherent tension between academic and commercial demands (Hackett 2001; West 2008). Universities have tried to over- 
come this tension in a number of ways, for instance, by establishing technology transfer offices (TTOs) (Siegel et al. 2007). Consequently, it may be valuable for resource-constraint boundary spanners (such as technology transfer offices) to identify those research scientists who are most likely to engage in entrepreneurial activities in order to focus their attention on a specific target group.

So far, within the literature on entrepreneurial intentions, there is ample evidence on individual drivers of entrepreneurial intentions (e.g., Dohse and Walter 2012; Lüthje and Franke 2003; Souitaris et al. 2007). Surprisingly, only few empirical studies have explored the role of organizational drivers for entrepreneurial intentions. Specifically, Lee et al. (2011) studied entrepreneurial intentions in a corporate setting and Walter et al. (2011) assessed the extent to which characteristics of university departments affect students' self-employment intentions. Similarly, the scarce research that has studied determinants of entrepreneurial intentions in academia has mainly focused on the individual level. Prodan and Drnovsek (2010) for instance found that entrepreneurial self-efficacy was the most important driver of entrepreneurial intentions and found smaller effects related to the type of research and the number of years the research scientist stayed at the institute. Goethner et al. (2012) showed that attitudes and perceived control were key determinants of entrepreneurial intentions in an academic context, whereas Obschonka et al. (2012) identified social identity as a central factor in explaining entrepreneurial intentions. Strikingly, while it is vital to understand the context in which the academic entrepreneur originates, to date, the organizational determinants of research scientists' entrepreneurial intentions remain an unexplored area.

Accordingly, this chapter aims at providing a better insight into the university characteristics that affect research scientists' propensity to engage in academic entrepreneurship. Specifically, we adopt an institutional perspective and focus on university culture and climate as factors shaping research scientists' intentions to create a university spin-off (hereafter: 'spin-off intentions'). Further, university spin-offs are defined as new ventures initiated within a university setting and based on technology derived from university research (Rasmussen and Borch 2010), and typically represent the central route to public research commercialization (Wright et al. 2008). We study our research question in a sample of 437 research scientists from six Swedish and German universities.

This article unfolds as follows. We first present our conceptual framework building on institutional theory, followed by a description of our research methodology. We subsequently present our results and discuss implications for academia, practice and future research.

\section{CONCEPTUAL FRAMEWORK}

Institutional theory has been widely used as explanatory framework in diverse research domains, ranging from marketing (e.g., Grewal and Dharwadkar 2002) over strategic management (e.g., Peng et al. 2009) to entrepreneurship (e.g., Bru- 
ton et al. 2010). Nevertheless, even among organizational theorists and sociologists, considerable variation exists in the definition of the central concepts of institution and institutionalization (DiMaggio and Powell 1983; Scott 1987).

This study approaches the organization as institution and draws upon a recently emerging stream in institutional theory, called 'new institutionalism' (DiMaggio \& Powell 1983, 1991; Scott 1987, 2001; Zucker 1987). Viewing the organization as an institution entails that implemented institutional elements generally arise from within the organization itself or from imitation of similar organizations, not from power or coercive processes located in the state (Zucker 1987). The neoinstitutional perspective rejects the rational-actor models of classical economics and utilizes cognitive and cultural explanations of social and organizational phenomena (DiMaggio and Powell 1991). Scott (2001, p.49) subsequently defines institutions as "multifaceted, durable social structures, made up of symbolic elements, social activities, and material resources", with the central components of institutions being rules (regulative), norms (normative) and values (cognitive). As institutions' rules, norms and values stipulate what is appropriate behavior, they render some actions unacceptable or even beyond consideration (DiMaggio and Powell 1991). Institutions are instrumental in shaping actors' goals and beliefs (Scott 1987) and in turn, affect motivational forces and behaviors (De Long and Fahey 2000; Szulanski 1996).

Accordingly, we argue that the organizational context in which research scientists are embedded might either trigger or restrain them from engaging in academic entrepreneurship, above and beyond individual-related characteristics. Despite a growing number of initiatives targeted at the 'third mission', universities still demonstrate large heterogeneity in their degree of institutional transformation (Tijssen 2006) and in their support for and involvement in entrepreneurial activities (Kenney and Goe 2004; Louis et al. 1989; Wright et al. 2008). Universities were traditionally developed to manage activities of research and teaching and, as such, these institutions have to be adapted to incorporate academic entrepreneurship. Universities hold distinct ideologies and trajectories towards their entrepreneurial role through which they exercise a strong influence on their members (Stankiewicz 1986).

Following the above arguments, we propose that university characteristics influence the extent to which research scientists intend to undertake entrepreneurial activities. In what follows, we focus on organizational culture and organizational climate and develop a conceptual framework linking these university characteristics to research scientists' entrepreneurial intentions. Organizational culture and climate are closely related, but distinct constructs (Kuenzi and Schminke 2009; Schein 2000). Both constructs conceptualize the way people experience and describe their work environment (Schneider et al. 2013). However, on the one hand, organizational culture may be defined as the beliefs and values that typify a setting and are taught to new members as the proper way to think, feel, and act within the organization (Schein 1985, Zohar \& Hofmann 2012). On the other hand, the concept of organizational climate designates how organizational policies, practices and procedures embed beliefs and values, as such communicating the organiza- 
tion's goals and the means through which employees can achieve those goals (Ostroff et al. 2003; Schneider et al. 1998). In other words, culture denotes assumptions, beliefs, meanings and values within an organization, whereas climate refers to the practices through which culture is manifested (Denison 1996). We contend that culture and climate constitute an integral part of the process of institutionalization transformation, as academic entrepreneurship is not equally embedded or formalized in all universities' values and practices.

\section{The relationship between organizational culture and spin-off intentions}

Adopting an institutional lens when examining culture is relevant (Zilber 2012), as it represents one important means by which normative and cognitive structures are transmitted (DiMaggio \& Powell 1991). Organizational culture provides meaning and context (Schein 1985) and affects how organizational members consciously and subconsciously think and make decisions. Ultimately, organizational culture has an impact on the way in which people perceive, feel and act (Hansen and Wernerfelt 1989). Organizational culture shapes the way organizational members set personal and professional objectives, perform tasks and administer resources to achieve them. Within this study, we follow Schein $(1985$, p. 9)'s definition of organizational culture as "a pattern of basic assumptions invented, discovered or developed by a given group as it learns to cope with its problems of external adaptation and internal integrations that has worked well enough to be considered valid, and therefore, to be taught to new members as the correct way to perceive, think, and feel in relation to those problems". Subsequently, organizational culture, acting through institutional belief systems and norms, can be a very effective means of directing the attitude and behavior of organizational members towards entrepreneurial activities.

Consequently, in order to increase research scientists' interest in entrepreneurial activities, universities could create a culture which is supportive towards such activities, alongside investments in tangible organizational units such as technology transfer offices, incubators and science parks. In this respect, Clark (1998) has identified an integrated entrepreneurial culture as a core ingredient for successful institutional transformations into entrepreneurial universities. Along the same lines, O'Shea et al. (2005) argue that universities need to develop a culture supportive of commercialization in order for academic entrepreneurship to flourish.

While there are numerous dimensions of organizational culture (Detert et al. 2000), this study examines two visible components of culture through which universities might influence research scientists' intentions to engage in entrepreneurial activities. Focusing on visible elements is appropriate, because organizational culture is more likely to be transmitted to organizational members through visible elements (values and behavioral patterns) than through invisible elements (basic 
assumptions) (Hofstede 1998; Schein 1985). In particular, we focus on the presence of a university mission that incorporates academic entrepreneurship and role models that exemplify academic entrepreneurship.

\section{Entrepreneurial university mission}

An organizational mission is a statement of the organization's reason for being, long term purpose and distinctiveness, reflecting the institutional beliefs systems and ideologies (Klemm et al. 1991; Swales and Rogers 1995). The development of an organizational mission is widely acknowledged to be a popular management tool, which requires effective communication to both organizational members and external stakeholders (Cochran and David 1986; Williams 2008). A large body of research has indicated that an organizational mission guides the individual behavior of organizational members (Bart 1996; Smith et al. 2001).

Historically, universities' missions were primarily directed towards research and teaching, turning their entrepreneurial transformation into a challenging task (Ambos et al. 2008). Institutional change typically requires and implies a modification of the culture or the key institutional elements that shape culture, including the mission (Schein 1985). As indicated by Jacob et al. (2003), the reconciliation of universities' traditional and entrepreneurial activities does not only require changes in infrastructure but also, amongst others, the adaptation of the university mission. Ideally, an entrepreneurial university should focus on research, teaching and entrepreneurial activities simultaneously (Etkowitz 2004; Guerrero and Urbano 2012).

Following institutional theory and given the tendency of organizational members to conform to organizational norms regarding entrepreneurship (Lewis et al. 2003; Peters and Fusfeld 1982), in particular in a university context (Friedman and Silberman 2003; Roberts 1991), it is likely that the university mission will affect research scientists' entrepreneurial intentions. Accordingly, we argue that the more universities highlight academic entrepreneurship as a fundamental part of their mission, the greater research scientists' intentions to engage in entrepreneurial endeavors will be. Thus,

Hypothesis 1. The extent to which a university mission emphasizes academic entrepreneurship compared to traditional activities is positively related to research scientists' spin-off intentions.

\section{Entrepreneurial university role models}

Role models constitute a second key element of organizational culture. The influence of role models on individuals has been highlighted in a number of contexts, including marketing and consumer behavior (Childers and Rao 1992; Martin and Bush 2000) and career development (Gibson 2003, 2004; Kram and Isabella 
1985). Role modeling refers to a cognitive process in which individuals observe attributes of people in social roles similar to themselves and increase this perceived similarity by imitating these attributes (Erikson 1985; Gibson 2004). Individuals are affected by institutional norms, or behavioral patterns of peers within their organization, and tend to act like them (Bercovitz and Feldman 2008; Haas and Park 2010; Jain et al. 2009). Since research scientists are exposed to a peeroriented culture (Samsom and Gurdon 1993), the internalization or imitation of institutional norms is expected to be strong (Lewis et al. 2003).

Specifically, it is well acknowledged that role models and peers play a crucial role in driving individuals' entrepreneurial activity (Falck et al. 2012; Nanda and Sorenson 2010; Thornton 1999). In a university context, the presence of entrepreneurial role models creates an example for research scientists and provides them with a feeling of security. Peer examples signify that academic entrepreneurship is accepted as a legitimate activity within the university, which reduces concerns about the social repercussions of own entrepreneurial actions (Stuart and Ding 2006). The findings of Shane (2004) and Bercovitz and Feldman (2008) support the view that research scientists' commercialization decisions are socially influenced.

Typically, individuals will imitate the particular behavior of their role models (Bandura 1986). Indeed, Prodan and Drnovsek (2010) provided evidence on the positive link between perceived role models of spin-off creation and research scientists' intentions to found a company themselves. Hence,

Hypothesis 2a. The presence of university role models involved in spin-off creation is positively related to research scientists' spin-off intentions.

Besides the direct impact of role models on entrepreneurial intentions through internalization or imitation, we expect the presence of role models to also indirectly affect entrepreneurial intentions, as a process of social comparison is likely to take place. Individuals judge their own abilities by comparing themselves to similar others (Festinger 1954). The presence of entrepreneurial role models will convince research scientists that they have what it takes to engage in entrepreneurial activities themselves. Consequently, role models may influence entrepreneurial self-efficacy, or an individual's confidence in his or her ability to successfully perform entrepreneurial roles and tasks (Chen et al. 1998). In turn, entrepreneurial self-efficacy may affect entrepreneurial intentions. Boyd and Vozikis (1994) developed a theoretical model in which self-efficacy was proposed as an important antecedent of entrepreneurial intentions. Empirical studies have provided strong support for the existence of such relationship (Chen et al. 1998; Krueger 1993; Chen et al. 1998; Zhao et al. 2005). Therefore, we assume that entrepreneurial role models will indirectly, i.e. through entrepreneurial self-efficacy, affect spin-off intentions. Thus, 
Hypothesis 2b. Entrepreneurial self-efficacy mediates the relation between university role models involved in spin-off creation and research scientists' spin-off intentions.

\section{The relationship between organizational climate and spin-off intentions}

Organizational climate is defined as the shared perceptions of and the meaning attached to policies, practices and procedures that organizational members experience, as well as the kinds of behaviors that are expected, rewarded and supported (Ostroff et al. 2003; Schneider et al. 1998). Climate reflects the tangible, cultureembedding mechanisms of organizations, through which they attempt to direct the energies of organizational members (Quinn and Rohrbaugh 1983; Schneider et al. 2013). Consequently, organizational climate is not identical, but closely related to organizational culture. Climate represents how culture is manifested through organizational policies and procedures, and how the organizational environment is perceived through the eyes of the individuals operating in that environment (Denison 1996; Reichers and Schneider 1990). As part of the institutional context, organizational climate exerts a strong influence on organizational members' motivation and behaviors (Brown and Leigh 1996; Kuenzi and Schminke 2009). Therefore, organizational climate can also influence individuals' attitudes and actions towards entrepreneurial activities.

Reward systems have often been seen as a focal dimension of organizational climate (Schneider et al. 1998). Extant literature has shown how organizational reward systems affect individual outcomes including motivation (e.g., Tyagi 1982), creativity (e.g., Shalley et al. 2004; Tesluk et al. 1997), job performance and satisfaction (e.g., Downey et al. 1975), affective commitment (e.g., Rhoades et al. 2001), knowledge sharing (e.g., Bartol and Srivastava 2002) and entrepreneurial behavior (e.g., Hornsby et al. 2002).

\section{Entrepreneurial university reward system}

Organizational rewards, be they monetary or non-monetary, reflect the organization's goals and objectives and encourage individual members to focus their attention on particular activities (Jensen 1993). Organizational members seek information concerning what activities are rewarded by their institution, and direct their behavior towards such activities while disregarding activities they are not rewarded for (Kerr 1975). Accordingly, through the implementation of specific reward systems, organizations can enhance the likelihood that desired behaviors occur.

In a university context, reward systems are typically based on research scientists' publication output (Franklin et al. 2001). Nevertheless, scholars have sug- 
gested that the establishment of rewards for entrepreneurial activities is needed in order to foster a climate of entrepreneurship within universities (Friedman and Silberman 2003; Shane 2004; Siegel et al. 2003). As such, if universities want to encourage their employees to engage in research commercialization, it will be desirable to adapt the incentive systems to the 'third mission' (Debackere and Veugelers 2005; Link et al. 2006; Markman et al. 2004). If reward systems are to stimulate research scientists to direct their efforts towards entrepreneurial activities, they should no longer be exclusively based on research and teaching excellence, but also reward entrepreneurial accomplishments (Henrekson and Rosenberg 2001; Jensen and Thursby 2001; Lockett and Wright 2005).

Following institutional theory and the literature on organizational reward systems, we can expect university rewards to affect research scientists' entrepreneurial intentions. Specifically, we argue that the more explicitly the university reward system incorporates entrepreneurial activities as a criterion compared to the rewards for research and teaching, the greater the research scientist's intentions to engage in entrepreneurial activities. Thus,

Hypothesis 3. The extent to which a university reward system incorporates academic entrepreneurship compared to traditional activities is positively related to research scientists' spin-off intentions.

Figure 1 summarizes our hypotheses.

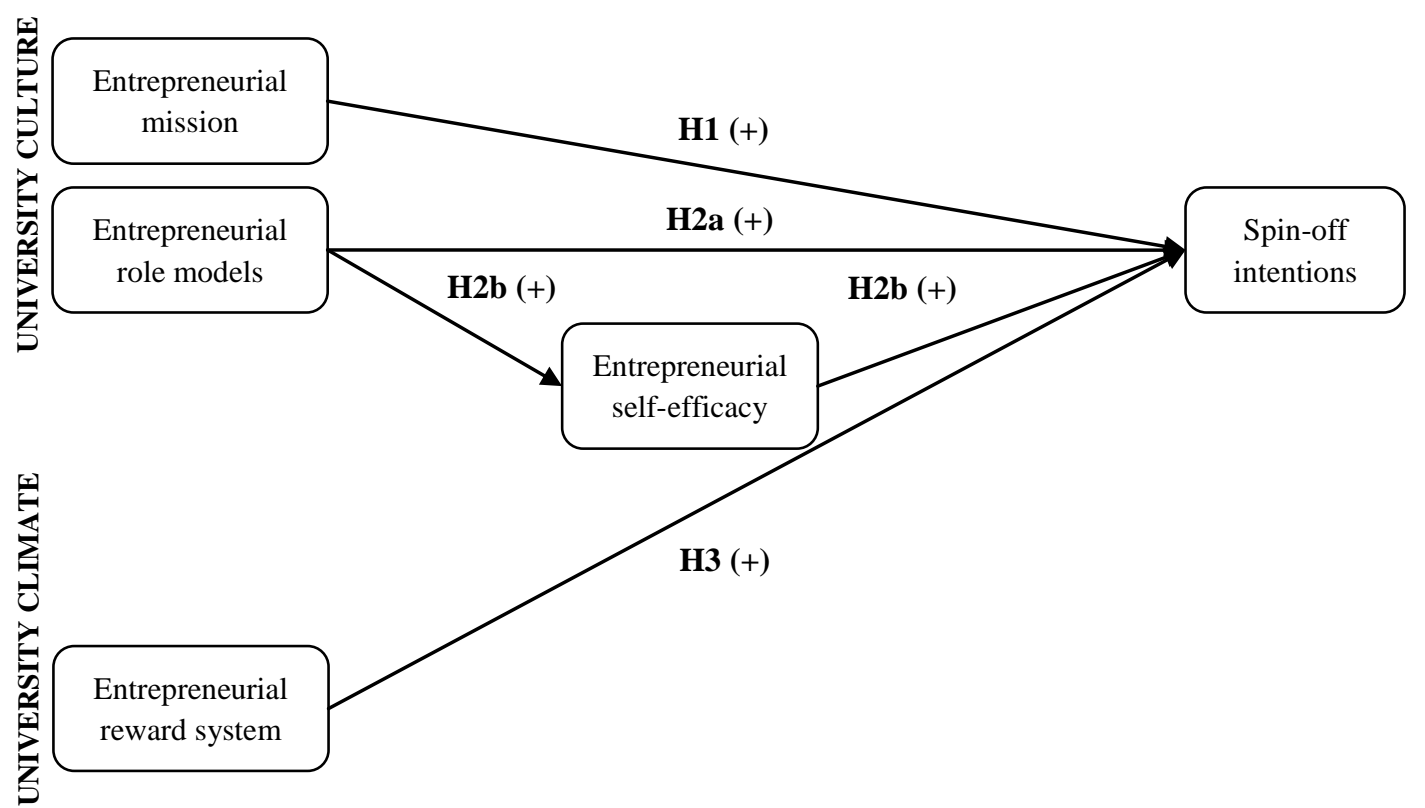

Fig. 1 Conceptual model 


\section{RESEARCH METHODOLOGY}

\section{Data collection and sample}

Our study is based upon unique cross-sectional data collected in 2012 at six universities in two European countries, Sweden and Germany. Both countries have similarly strong and mature infrastructural support for entrepreneurial activities initiated by both government and individual universities. Sweden and Germany are characterized by high levels of R\&D intensity and a relatively high degree of academic entrepreneurship (Wright et al. 2008). An important difference lies in the academic exemption or professor's privilege in Sweden, which asserts full ownership of intellectual property rights to faculty (Klofsten and Jones-Evans 2000). For both countries, we compiled a list of all universities using secondary data (including reports by ministries of education, university rankings, technology transfer networks and general internet searches). Next, we selected one or two geographical regions within each country (i.e. Gothenburg, Stockholm and Munchen region) and contacted all universities' TTO through email or phone, which resulted in full participation from 6 out of 15 TTOs contacted.

The data collection process included face-to-face interviews with technology transfer officers from each university, followed by an online survey for research scientists involved in different scientific disciplines. First, we contacted the technology transfer offices from the six universities (Chalmers University of Technology, Gothenburg University, Mälardalen University, Halmstad University, KTH Royal Institute of Technology and Technical University Munchen). Through faceto-face interviews, we obtained information on university characteristics (e.g., human and financial resources, annual innovation output) and technology transfer practices (e.g., history and organizational structure). Primary data were verified and complemented with secondary data from annual reports, university and TTO websites. Furthermore, we asked permission and assistance to contact research scientists at each university. We specifically targeted research scientists (as opposed to, for instance, tenured professors) because research scientists (i.e. doctoral and post-doctoral positions) are more likely to develop their career capital due to uncertainty about which career track will be the most beneficial to them (Krabel and Mueller 2009). In contrast, professors are typically more focused on establishing their reputation in the scientific community.

The survey population consisted of 8,857 research scientists, of which 5,418 at the Swedish universities and 3,439 at the German universities. Respondents received a request through email to complete an online questionnaire. We obtained 1,103 failure messages indicating that email addresses were invalid or our message could not be sent, resulting in a usable population of 7,754 research scientists. After one week, a reminder email was sent. In total, 850 responses were re- 
ceived (or $11 \%$ of the usable population). After elimination of incomplete responses, our final sample consists of 437 research scientists who fully completed the questionnaire, or $5.6 \%$ of the usable population. T-tests revealed no significant differences between respondents who filled in all questions and those who provided incomplete responses, or between early and late respondents, in terms of age, gender, education, position, academic experience or country ( $\mathrm{p}>0.05)$. As such, non-response bias was unlikely to be a problem in our dataset (Hair et al. 2006). Some procedural techniques were used to reduce the risk of common method bias. In our email, we guaranteed anonymity to reduce respondents' tendency to give socially desirable answers (Podsakoff et al. 2003). Moreover, careful attention was given to the wording of questions in order to avoid vague concepts and to reduce items' ambiguity (Tourangeau et al. 2000).

\section{Measures}

\section{Dependent variable}

Spin-off intentions were measured by the following items: 'How likely is it that, in the foreseeable future, 1) You will engage in the founding of a university spinoff?, 2) You will engage in the establishment of a company based upon an idea and/or technology developed at the university? and 3) You will participate in the founding of a firm to commercialize your research?', on a scale ranging from 1 (very unlikely) to 7 (very likely). Scale reliability measured by Cronbach's alpha is 0.92 .

\section{Independent variables}

University mission. Drawing upon Guerrero and Urbano (2012), we created 7 items to measure whether the university mission incorporates academic entrepreneurship. Respondents were asked to indicate their degree of agreement with the following statements on a scale ranging from 1 (strongly disagree) to 7 (strongly agree): 'The mission of my university focuses on 1) Publishing papers with practical implications, 2) Knowledge transfer (patents, licenses, spin-offs), 3) Promoting an entrepreneurial culture, 4) Generating entrepreneurs, 5) Publishing scientific, peer-reviewed papers, 6) Academic excellence (research and teaching) and 7) Consulting and contract research with industry.' Exploratory factor analysis pointed to the existence of two factors: 'focus on traditional activities' (items 5 and 6; Cronbach's alpha 0.78) and 'focus on entrepreneurial activities' (items 1, 2, 3, 4 and 7; Cronbach's alpha 0.84). Subsequently, we summarized these items in two constructs and divided the values obtained for the first construct by the latter con- 
struct. As such, our variable labeled 'Entrepreneurial mission' expresses the relative importance of 'third mission' within the university mission, as perceived by the research scientists.

University role models. Participants were asked: 'Has anyone in your university, who you know personally, created a company based on university research?'. Responses were coded 1 (41\% of the sample) in case of perceived spin-off role models and 0 otherwise. As such, a dummy variable was generated, labeled 'Spin-off role models'.

University reward system. We created 6 items to reflect whether the university reward system values academic entrepreneurship, beyond the traditional, scientific activities of teaching and research. Using a 7-point Likert scale ranging from 1 (strongly disagree) to 7 (strongly agree), respondents were requested to answer the following statements: 'My rewards (e.g., salary, additional financial resources, recognition from scientific community, flexi-time...) are determined by 1) Research performance (e.g., number and quality of publications), 2) Involvement in consulting and contract research, 3) Involvement in administrative, service or committee activities, 4) Involvement in patenting and licensing, 5) Teaching performance (e.g., student evaluations) and 6) Involvement in spin-off creation'. The exploratory factor analysis revealed two factors: 'emphasis on traditional rewards' (items 1, 3 and 5; Cronbach's alpha 0.70) and 'emphasis on entrepreneurial rewards' (items 2, 4 and 6; Cronbach's alpha 0.88). We again generated summarized measures for the two constructs and calculated the relative importance of entrepreneurial rewards compared to traditional rewards. The measure we obtained was labeled 'Entrepreneurial rewards'.

\section{Other variables}

Following prior literature on academic entrepreneurship and entrepreneurial intentions, other characteristics could affect research scientists' entrepreneurial intentions. In what follows, we elaborate on our mediating and control variables.

Entrepreneurial self-efficacy was measured using the scale developed and validated by Zhao et al. (2005), including four items: 'How confident are you in successfully 1) Identifying new business opportunities?, 2) Creating new products?, 3) Thinking creatively? and 4) Commercializing an idea or new development?' (1 $=$ no confidence, $7=$ complete confidence). Scale reliability measured by Cronbach's alpha is 0.81 .

Gender $(0=$ male, 1 = female $)$ was controlled for as men are usually more entrepreneurial than women (Crant 1996; Zhao et al. 2005).

Position ( $0=$ doctoral researcher, 1 = post-doctoral researcher) indicates whether the respondent has already obtained a $\mathrm{PhD}$ or not.

Technical degree (e.g., bio-science, physics, electronics, mechanics, robotics, ...) and non-technical degree (e.g., economics, law school, psychology, MBA, ...) assesses the degree research scientists obtained $(0=$ no, $1=$ yes $)$. Education is a 
key element of human capital which has been shown to affect the likelihood of becoming an entrepreneur (Mosey and Wright 2007; Shane 2000).

Academic experience indicates the number of years respondents have so far spent in academia. Research scientists' embeddedness in academia may lower the likelihood of producing commercial outputs (Ambos et al. 2008).

Medicine was included as a dummy variable (coded 1 if a research scientist performs research on clinical medicine or pharmacy, 0 otherwise), as medical inventions have greater marketability than inventions from other disciplines (Powers 2003). Further, research scientists at medical faculties are typically more familiar with working at the intersection of basic and applied research (Stuart and Ding 2006).

Country was controlled for, given the academic exemption or professor's privilege in Sweden (Klofsten and Jones-Evans 2000), by including a dummy variable $(0=$ Germany, $1=$ Sweden $)$.

\section{Discriminant validity and common method variance}

Before testing our hypotheses, we ran confirmatory factor analyses to check the distinctiveness of our measures (discriminant validity) and to rule out the impact of common method bias. Discriminant validity was assessed for pairs of constructs by constraining the estimated correlation parameter between constructs to 1 and then performing a chi-square difference test on the values obtained from the constrained and unconstrained models (Anderson and Gerbing 1988). For all 10 pairs of constructs, the chi-square values were significantly lower for the unconstrained models (i.e. $\Delta \chi_{\mathrm{df}=1}^{2}>3.84$ ), which indicates discriminant validity. Furthermore, we wanted to verify whether our results were affected by common method variance, which is a legitimate concern when all variables are gathered through a questionnaire (Podsakoff et al. 2003). Thus, we added a latent variable which was allowed to influence all items of our base model in which all items were allowed to load on their respective latent constructs. This additional latent variable represents the common method extracted from all items (Podsakoff et al. 2003). While CFI and SRMR fit indices indicate that this model is somewhat better than the model without common method variable, PNFI, which takes into account a model's parsimony and hence helps compare models (Hair et al. 2006), was higher for the model without the common method factor $(0.75$ versus 0.65$)$, pointing to a better model fit. This indicates that common method variance was not a major concern in our study. 
Table 1 Descriptive statistics and correlations

\begin{tabular}{|c|c|c|c|c|c|c|c|c|c|c|c|c|c|c|}
\hline & Variable & Mean & $\mathrm{SD}$ & (1) & (2) & (3) & (4) & (5) & (6) & (7) & (8) & (9) & (10) & (11) \\
\hline (1) & Gender $^{\mathrm{a}}$ & 0.41 & 0.49 & & & & & & & & & & & \\
\hline (2) & Position $^{\mathrm{a}}$ & 0.25 & 0.43 & 0.05 & & & & & & & & & & \\
\hline (3) & Technical degree ${ }^{a}$ & 0.62 & 0.49 & $-0.21 * *$ & $-0.14^{* *}$ & & & & & & & & & \\
\hline (4) & Non-technical degree ${ }^{\mathrm{a}}$ & 0.34 & 0.47 & $0.18^{* *}$ & $0.14^{* *}$ & $-0.75 * *$ & & & & & & & & \\
\hline (5) & Academic experience & 7.59 & 6.57 & -0.06 & $0.36^{* *}$ & $-0.17 * *$ & $0.16^{* *}$ & & & & & & & \\
\hline (6) & Medicine $^{a}$ & 0.21 & 0.41 & $0.18^{* *}$ & $0.12 * *$ & $-0.31 * *$ & $0.17^{* *}$ & $0.19^{* *}$ & & & & & & \\
\hline (7) & ESE & 3.80 & 1.27 & $-0.23 * *$ & $-0.08 *$ & $0.16^{* *}$ & $-0.14 * *$ & 0.04 & $-0.12 * *$ & & & & & \\
\hline (8) & Country $^{\mathrm{a}}$ & 0.64 & 0.48 & $0.09^{*}$ & $0.12^{* *}$ & $-0.22 * *$ & $0.24 * *$ & $0.23^{* *}$ & $0.31 * *$ & $-0.14 * *$ & & & & \\
\hline (9) & Entrepreneurial mission & 0.83 & 0.33 & $-0.15 * *$ & $-0.09 *$ & $0.12 * *$ & $-0.12 * *$ & -0.03 & $-0.17 * *$ & $0.18^{* *}$ & $-0.11 *$ & & & \\
\hline (10) & Spin-off role models & 0.41 & 0.49 & -0.08 & $0.11^{* *}$ & $0.10^{*}$ & $-0.11 * *$ & $0.11^{* *}$ & 0.01 & $0.19^{* *}$ & 0.01 & 0.05 & & \\
\hline (11) & Entrepreneurial rewards & 0.74 & 0.51 & -0.08 & -0.08 & $0.11 *$ & $-0.17^{* *}$ & $-0.09 *$ & -0.03 & $0.21 * *$ & -0.07 & $0.18^{* *}$ & $0.13 * *$ & \\
\hline (12) & Spin-off intentions & 2.89 & 1.61 & $-0.17 * *$ & -0.06 & $0.23 * *$ & $-0.16^{* *}$ & -0.04 & $-0.08^{*}$ & $0.55^{* *}$ & -0.02 & $0.23 * *$ & $0.23 * *$ & $0.27 * *$ \\
\hline
\end{tabular}

Pearson correlation coefficient (1-tailed): $* \mathrm{p}<0.05, * * \mathrm{p}<0.01 ; \mathrm{n}=437$

${ }^{\mathrm{a}}$ Correlations of binary variables should be interpreted with care. 


\section{RESULTS}

Table 1 provides the means, standard deviations and correlations for all variables. Our sample consists of 281 (64\%) Swedish and 156 (36\%) German research scientists. $41 \%$ of our respondents are women and $25 \%$ are post-docs. In addition, 269 $(62 \%)$ research scientists in our sample possess a technical degree (science, technology or engineering) and $148(34 \%)$ a non-technical degree (business, social sciences or humanities). On average, respondents indicated having 7.59 years of experience in academia (SD 6.57 years). 93 respondents $(21 \%)$ are involved in clinical medicine or pharmaceutical research.

Hierarchical OLS regressions were performed to evaluate the direct relationships (Hypothesis 1, 2a and 3). In the first model, we entered only the control variables, while the independent variables were added in the second model. We checked for multicollinearity problems by calculating variance inflation factors (VIFs) for all models. The highest VIF was 1.1 , which is substantially below the critical value of 5 (Hair et al. 2006) and indicates that multicollinearity is unlikely to be a concern in our study. Our results are presented in Table 2.

Model 1 is the baseline model consisting of control variables only. Results indicate that research scientists holding a technical degree (science, technology, or engineering) have higher intentions to engage in spin-off creation $(\mathrm{p}<0.01)$. Further, in line with prior research (Prodan and Drnovsek 2010; Zhao et al. 2005), entrepreneurial self-efficacy positively affects research scientists' entrepreneurial intentions $(p<0.001)$. Finally, a significant country effect $(p<0.05)$ exists, with Swedish research scientists showing higher intentions to found a company based on university research compared to their German colleagues.

Models 2 presents the results for the direct effects of culture and climate on entrepreneurial intentions, whilst controlling for individual characteristics and country effects. In each of our full models, adding independent variables to the baseline model leads to significant improvements of $\mathrm{R}^{2}(\mathrm{p}<0.001)$. We find support for Hypothesis 1, which proposed that the degree to which a university mission highlights academic entrepreneurship relative to its traditional tasks is positively associated with research scientists' spin-off intentions $(\mathrm{p}<0.01)$. Hypothesis $2 a$, which looked at the direct relationship between university role models and research scientists' entrepreneurial intentions, is also supported. The presence of spin-off role models is positively related to spin-off intentions $(\mathrm{p}<0.01)$. Our findings also support Hypothesis 3, which states that the explicitness of academic entrepreneurship as criterion in the university reward system, compared to research and teaching, is positively related to research scientists' entrepreneurial intentions. Entrepreneurial rewards has a significant positive influence on spin-off intentions $(\mathrm{p}<0.001)$. 
Table 2 OLS regression model coefficients (standard errors in parentheses)

\begin{tabular}{|c|c|c|}
\hline & \multicolumn{2}{|c|}{ Spin-off intentions } \\
\hline & Model 1 & Model 2 \\
\hline Constant & $\begin{array}{l}-0.206 \\
(0.312)\end{array}$ & $\begin{array}{l}-0.925^{* *} \\
(0.343)\end{array}$ \\
\hline \multicolumn{3}{|l|}{ Control variables } \\
\hline Gender & $\begin{array}{l}-0.103 \\
(0.136)\end{array}$ & $\begin{array}{l}-0.05 \\
(0.133)\end{array}$ \\
\hline Position & $\begin{array}{l}0.057 \\
(0.158)\end{array}$ & $\begin{array}{l}0.043 \\
(0.154)\end{array}$ \\
\hline Technical degree & $\begin{array}{l}0.609 * * \\
(0.205)\end{array}$ & $\begin{array}{l}0.627 * * \\
(0.199)\end{array}$ \\
\hline Non-technical degree & $\begin{array}{l}0.132 \\
(0.205)\end{array}$ & $\begin{array}{l}0.267 \\
(0.201)\end{array}$ \\
\hline Academic experience & $\begin{array}{l}-0.018 \\
(0.011)\end{array}$ & $\begin{array}{l}-0.018 \\
(0.011)\end{array}$ \\
\hline Medicine & $\begin{array}{l}0.079 \\
(0.173)\end{array}$ & $\begin{array}{l}0.109 \\
(0.169)\end{array}$ \\
\hline Entrepreneurial self-efficacy & $\begin{array}{l}0.687 * * * \\
(0.052)\end{array}$ & $\begin{array}{l}0.612 * * * \\
(0.052)\end{array}$ \\
\hline Country & $\begin{array}{l}0.340 * \\
(0.144)\end{array}$ & $\begin{array}{l}0.342 * \\
(0.140)\end{array}$ \\
\hline \multicolumn{3}{|l|}{ Independent variables } \\
\hline Entrepreneurial mission & & $\begin{array}{l}0.576 * * \\
(0.195)\end{array}$ \\
\hline Spin-off role models & & $\begin{array}{l}0.341 * * \\
(0.130)\end{array}$ \\
\hline Entrepreneurial rewards & & $\begin{array}{l}0.409 * * * \\
(0.127)\end{array}$ \\
\hline F-statistic & $27.350 * * *$ & $24.007 * * *$ \\
\hline $\mathrm{R}^{2}$ & 0.34 & 0.38 \\
\hline Adjusted $\mathrm{R}^{2}$ & 0.33 & 0.37 \\
\hline $\mathrm{R}^{2}$ change & & $0.04 * * *$ \\
\hline
\end{tabular}

$* \mathrm{p}<0.05, * * \mathrm{p}<0.01, * * * \mathrm{p}<0.001 ; \mathrm{n}=437$

In order to test for the indirect relationship between university role models and intentions through entrepreneurial self-efficacy (Hypothesis 2b), we used a macro developed by Preacher and Hayes (2008). This allows us to disentangle the impact of direct and indirect (mediaton) effects and relies on bootstrapping to test the mediation effect. The results are shown in Figure 2. 


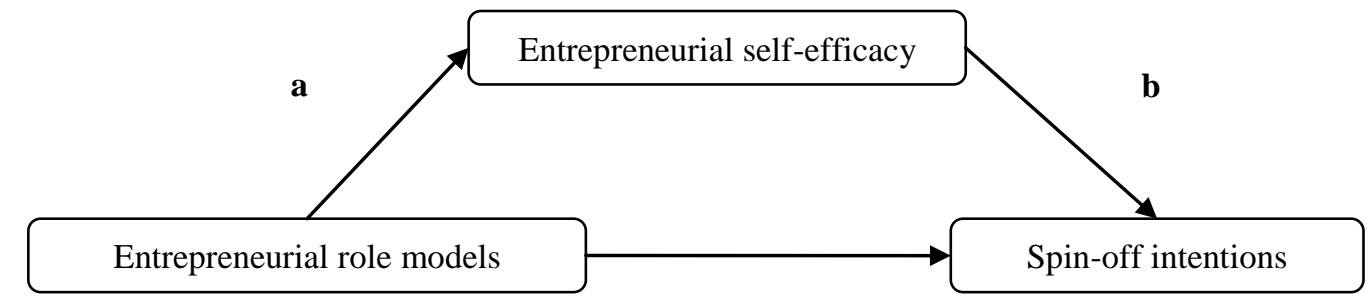

c

Total effect $=$ Indirect effect + Direct effect

$=(\mathrm{a} \times \mathrm{b})+\mathrm{c}$

\begin{tabular}{cccc}
\hline $\mathrm{a}$ & $\mathrm{b}$ & Bootstrap-indirect effect & $95 \% \mathrm{CI}$ \\
\hline $0.3794 *$ & $0.6120 * * *$ & 0.2322 & $0.0870-0.4053$ \\
$(0.2768)$ & $(0.0523)$ & $(0.0809)$ & \\
\hline
\end{tabular}

$* \mathrm{p}<0.05, * * \mathrm{p}<0.01, * * * \mathrm{p}<0.001 ; \mathrm{n}=437$

F-statistic is significant at $0.1 \%$ level. Confidence interval (CI) is bias-corrected based on 10,000 bootstrap samples. Covariates included: gender, position, technical degree, non-technical degree, academic experience, medicine,

Fig. 2 Diagram of the mediation effect

Figure 2 displays the significance of the indirect effects, in particular the extent to which entrepreneurial self-efficacy mediates the relationship between university role models and entrepreneurial intentions. The indirect effect of spin-off role models on spin-off intentions via entrepreneurial self-efficacy is positive and significant $(95 \% \mathrm{CI}=0.087-0.405)$. This provides support for Hypothesis $2 b$.

\section{Robustness checks}

We conducted post hoc analyses to assess the robustness of our results and to provide more fine-grained insights into the impact of organizational culture and climate on research scientists' entrepreneurial intentions. Specifically, while we deliberately assessed organizational culture and climate through the perceptions of research scientists, it is relevant to verify the degree to which people within an organization agree in their perceptions (Schneider et al. 2013). We subsequently calculated the (two-way random) intra-class correlation coefficients (ICCs) for the responses received on the items for mission and reward system for each university. ICC(2) is an index of the reliability of the group means and is commonly interpreted in line with other measures of reliability, with 0.70 or higher deemed adequate (Bliese 2000; LeBreton and Senter 2008). All ICCs were significantly above this generally accepted minimum value, with the lowest ICC equaling 0.89 . This 
points to considerable convergence in the opinions of research scientists on the university mission and reward system.

\section{DISCUSSION AND CONCLUSIONS}

This chapter has sought to contribute to our understanding of how organizational culture and climate affect entrepreneurial intentions in academia, thereby adopting an institutional perspective. Our study provides evidence that universities can shape research scientists' intentions to engage in spin-off creation, by offering an institutional environment that promotes academic entrepreneurship. First, our analyses reveal interesting insights into the influence of organizational culture on entrepreneurial intentions. Particularly, the more universities emphasize academic entrepreneurship in their mission compared to research and teaching, the greater research scientists' intentions to engage in spin-off creation. Furthermore, a second element of university culture, the presence of spin-off role models leads to stronger intentions among research scientists to engage in spin-off creation. At the same time, entrepreneurial role models also exert an indirect influence on entrepreneurial intentions through an increase of research scientists' entrepreneurial self-efficacy. Specifically, research scientists who detect entrepreneurial role models in their university feel more confident that they could successfully engage in entrepreneurial activities themselves, and are therefore more likely to hold entrepreneurial intentions. Second, as for organizational climate, research scientists working at universities which explicitly allocate rewards for entrepreneurial endeavors were found to possess higher levels of entrepreneurial intentions.

This study contributes to the academic literature in a number of ways. First, this study contributes to the academic entrepreneurship literature, in which entrepreneurial intentions have only recently started to receive attention. Specifically, we use an institutional lens to study the impact of organizational context on entrepreneurial intentions, while controlling for individual factors. Importantly, whereas university culture has been identified as a key driver for academic entrepreneurship (Clark 1998; Jacob et al. 2003, Martinelli et al. 2008; Siegel et al. 2004), to this point no research has provided a theoretical framework nor empirical evidence on the association between university culture and the development of entrepreneurial intentions. As such, this research responds to recent calls by Djokovic and Souitaris (2008) to untangle the impact of an entrepreneurial culture within the university and by O'Shea et al. (2005) to explain academic entrepreneurship in terms of university culture and rewards. Particularly, we show that elements of organizational culture, namely university mission and the presence of role models, just as organizational climate, including the extent to which the university reward system values entrepreneurial activities, have an important effect on research scientists' entrepreneurial intentions. Second, this chapter enriches the entrepreneurial intentions literature which has predominantly focused on individual-level explanations of entrepreneurial intentions, but has to a large extent neglected 
organizational determinants. Given that individuals are embedded in institutional contexts, they cannot be studied in an isolated manner. Accordingly, we respond to a call by Dohse and Walter (2012) to contextualize entrepreneurial intentions.

Our research also has relevant implications for practitioners, including policy makers and university management. First, for policy makers, who base university funding upon evaluation criteria including a mix of research, teaching and entrepreneurial activities (Etzkowitz et al. 2000), it may be useful to understand how the universities they finance could enhance their commercialization output. Consequently, for instance, they could help to increase this output by stimulating universities to include entrepreneurial activities as part of the reward system. Second, for university management, this research shows that it is beneficial to incorporate academic entrepreneurship in the university mission and to make sure that research scientists are aware of existing role models. While examining the mechanisms through which university management could communicate that entrepreneurship is a fundamental part of the university mission was beyond the scope of our study, it is likely that any sort of communication (newsletters, speeches by university management) that increases the awareness among research scientists of the importance of entrepreneurial activities within their university will generate higher levels of entrepreneurial intentions. Furthermore, university management could ensure that role models make public appearances more frequently and as such, focus research scientists' attention on academic entrepreneurship as an ongoing and accepted organizational practice. Finally, university management could establish a reward system that does not only value scientific output, but also distributes rewards for research scientists' engagement in entrepreneurial activities.

Our study has a number of limitations which suggest fruitful areas for further research. First, data were collected at six universities in Germany and Sweden. While we find limited country differences based upon our analyses, there is little reason to assume that our results could not be generalized to other regions in Europe. Yet, further research could broaden the geographical scope and develop similar studies in other countries or study universities in a broader range of contexts. Also, future studies could assess to which extent our results hold in samples of public research institutions or university colleges. Second, while our results indicate that raising awareness of an entrepreneurial mission or role models is conducive to entrepreneurial intentions, our study does not provide insights into how such awareness could be generated by universities and what communication mechanisms yield the better result. Consequently, future research could explore how to make research scientists optimally aware of the organizational culture in order to direct their behavior towards entrepreneurial activities. Third, our data collection is cross-sectional in nature. As such, we are unable to assess the impact of changes in the university mission or reward system on entrepreneurial intentions, nor to evaluate under which organizational conditions entrepreneurial intentions actually translate into entrepreneurial behavior. We encourage future studies to employ longitudinal research designs to shed light on these issues. Finally, this chapter deliberately focused on institutional characteristics at the level of the university. While we controlled for individual-level factors that have been found to 
affect entrepreneurial intentions, future research could purposefully assess which individual-level and organizational-level determinants reinforce each other, applying multilevel analysis techniques. Along the same lines, we call for research that further disentangles the impact of institutional context on entrepreneurial intentions, by including characteristics both at university and departmental level. Specifically, given that organizational culture may exist for a whole organization but also simultaneously in the form of subcultures (Schneider et al. 2013), a strong entrepreneurial spirit at the institutional level without support from local levels might have a less effective impact on research scientists' entrepreneurial intentions.

In spite of these limitations, to our knowledge, this chapter is the first to address the impact of organizational characteristics on entrepreneurial intentions in an academic context. Controlling for individual characteristics and considering academic entrepreneurship in a broad sense, we found that university culture and climate largely affect research scientists' spin-off intentions.

Acknowledgments The authors would like to thank the interviewed technology transfer officers for their participation, as well as all respondents who completed the online survey. The first author also gratefully acknowledges the financial support provided by Research Foundation Flanders (FWO) in undertaking this research. We would further like to thank the organizers and participants of the T2S Conference in Bergamo, November 2013, for their feedback on this chapter.

\section{References}

Ambos, T. C., Makela, K., Birkinshaw, J., \& D'Este, P. (2008). When does university research get commercialized? Creating ambidexterity in research institutions. Journal of Management Studies, 45(8), 1424-1447.

Anderson, J. C., \& Gerbing, D.W. (1988). Structural equation modeling in practice: A review and recommended two-step approach. Psychological Bulletin, 103(3), 411-423.

Bandura, A. (1986). Social foundations of thought and action: A social cognitive theory. Englewood Cliffs, NJ: Prentice-Hall.

Bart, C. K. (1996). High tech firms: Does mission matter? The Journal of High Technology Management Research, 7(2), 209-225.

Bartol, K. M., \& Srivastava, A. (2002). Encouraging knowledge sharing: The role of organizational reward systems. Journal of Leadership \& Organizational Studies, 9(1), 64-76.

Bercovitz, J., \& Feldman, M. (2008). Academic entrepreneurs: Organizational change at the individual level. Organization Science, 19(1), 69-89.

Bird, B. (1988). Implementing entrepreneurial ideas : The case for intention. Academy of Management Review, 13(3), 442-453.

Bliese, P. D. (2000). Within-group agreement, non-independence, and reliability: Implications for data aggregation and analyses. In K. J. Klein, \& S. W. J., Kozlowski (Eds.), Multilevel theory, research and methods in organizations: Foundations, extensions, and new directions (pp. 349-381). San Francisco: Jossey-Bass.

Boyd, N. G., \& Vozikis, G. S. (1994). The influence of self-efficacy on the development of entrepreneurial intentions and actions. Entrepreneurship Theory and Practice, 18(4), 63-77.

Brown, S. P., \& Leigh, T. W. (1996). A new look at psychological climate and its relationship to job involvement, effort, and performance. Journal of Applied Psychology, 81(4), 358-368. 
Bruton, G. D., Ahlstrom, D., \& Li, H. (2010). Institutional theory and entrepreneurship: Where are we now and where do we need to move in the future? Entrepreneurship Theory and Practice, 34(3), 421-440.

Chen, C. C., Greene, P. G., \& Crick, A. (1998). Does entrepreneurial self-efficacy distinguish entrepreneurs from managers? Journal of Business Venturing, 13, 295-316.

Childers, T. L., \& Rao, A. R. (1992). The influence of familial and peer-based reference groups on consumer decisions. Journal of Consumer Research, 19(2), 198-211.

Clark, B. R. (1998). Creating entrepreneurial universities: organizational pathways of transformation. Issues in higher education. New York: Elsevier.

Cochran, D. S., \& David, F. R. (1986). Communication effectiveness of organizational mission statements. Journal of Applied Communication Research, 14(2), 108-118.

Crant, J. M. (1996). The proactive personality scale as a predictor of entrepreneurial intentions. Journal of Small Business Management, 34(3), 42-49.

De Long, D. W., \& Fahey, L. (2000). Diagnosing cultural barriers to knowledge management. Academy of Management Executive, 14(4), 118-127.

Debackere, K., \& Veugelers, R. (2005). The role of academic technology transfer organizations in improving industry science links. Research Policy, 34, 321-342.

Denison, D. R. (1996). What is the difference between organizational culture and organizational climate? A native's point of view on a decade of paradigm wars. Academy of Management Review, 21(3), 619-654.

Detert, J. R., Schroeder, R. G., \& Mauriel, J. J. (2000). A framework for linking culture and improvement initiatives in organizations. Academy of Management Review, 25(4), 850-863.

DiMaggio, P. J., \& Powell, P. W. (1983). The iron cage revisited: Institutional isomorphism and collective rationality in organizational fields. American Sociological Review, 48(2), 147-60.

DiMaggio, P. J., \& Powell, P. W. (1991). The new institutionalism in organizational analysis. Chicago: University of Chicago Press.

Djokovic, D., \& Souitaris, V. (2008). Spinouts from academic institutions: a literature review with suggestions for further research. Journal of Technology Transfer, 33(3), 225-247.

Dohse, D., \& Walter, S. (2012) Knowledge context and entrepreneurial intentions among students. Small Business Economics. 39(4), 877-895.

Downey, H. K, Hellriegel, D., \& Slocum, J. W. (1975). Congruence between individual needs, organizational climate, job satisfaction and performance. Academy of Management Journal, 18(1), 149-155.

Erikson, E. H. (1985). Childhood and society. New York: W.W. Norton.

Etkowitz, H. (2004). The evolution of the entrepreneurial university. International Journal of Technology and Globalisation, 64-77.

Etzkowitz, H. (2003). Research groups as 'quasi-firms': The invention of the entrepreneurial university. Research Policy, 32(1), 109-121.

Etzkowitz, H., Webster, A., Gebhardt, C., \& Terra, B. (2000). The future of the university and the university of the future: Evolution of ivory tower to entrepreneurial paradigm. Research Policy, 29(2), 313-330.

Falck, O., Heblich, S., \& Luedemann, E. (2012). Identity and entrepreneurship: Do school peers shape entrepreneurial intentions? Small Business Economics, 39(1), 39-59.

Festinger, L. (1954). A theory of social comparison processes. Human Relations, 7, 117-140

Fishbein, M., \& Ajzen, I. (1975). Belief, attitude, intention, and behaviour: An introduction to theory and research. New York: Addison-Wesley

Franklin, S., Wright, M., \& Lockett, A. (2001). Academic and surrogate entrepreneurs in university spin-out companies. Journal of Technology Transfer, 26, 127-141.

Friedman, J., \& Silberman, J. (2003). University technology transfer: Do incentives, management and location matter? Journal of Technology Transfer, 28(1), 17-30.

Gibson, D. E. (2003). Developing the professional self-concept: Role model construals in early, middle, and late career stages. Organization Science, 14(5), 591-610.

Gibson, D. E. (2004). Role models in career development: New directions for theory and research. Journal of Vocational Behavior, 65(1), 134-156. 
Goethner, M., Obschonka, M., Silbereisen, R., \& Cantner, U. (2012). Scientists' transition to academic entrepreneurship: Economic and psychological determinants. Journal of Economic Psychology, 33, 628-641.

Grewal, R., \& Dharwadkar, R. (2002). The role of the institutional environment in marketing channels. Journal of Marketing, 66(3), 82-97.

Guerrero, M., \& Urbano, D. (2012). The development of an entrepreneurial university. Journal of Technology Transfer, 37(1), 43-74.

Haas, M. R., \& Park, S. (2010). To share or not to share? Professional norms, reference groups, and information withholding among life scientists. Organization Science, 21(4), 873-891.

Hackett, E. (2001). Organizational perspectives on university-industry research relations. In J. R. Croissant, S. (Ed.), Degrees of Compromise (pp. 1-21). Albany, New York: State University of New York Press.

Hair, J. F., Black, W. C., Babin, B. J., Anderson, R. E., \& Tatham, R. L. (2006). Multivariate data analysis. Upper Saddle River, NJ: Pearson.

Hansen, G. S., \& Wernerfelt, B. (1989). Determinants of firm performance: The relative importance of economic and organizational factors. Strategic Management Journal, 10(5), 399. 411.

Henrekson, M., \& Rosenberg, N. (2001). Designing efficient institutions for science-based entrepreneurship: Lesson from the US and Sweden. Journal of Technology Transfer, 26(3), 207-231.

Hofstede, G. (1998). Attitudes, values and organizational culture: Disentangling the concepts, Organization Studies, 19(3), 477-493.

Hornsby, J. S., Kuratko, D.F., \& Zahra, S.A. (2002). Middle managers' perception of the internal environment for corporate entrepreneurship: Assessing a measurement scale. Journal of Business Venturing, 17(3), 253-273.

Jacob, M., Lundqvist, M., \& Hellsmark, H. (2003). Entrepreneurial transformations in the Swedish university system: The case of Chalmers University of Technology. Research Policy, 32(9), 1555-1568.

Jain, S., George, G., \& Maltarich, M. (2009). Academics or entrepreneurs? Investigating role identity modification of university scientists involved in commercialization activity. Research Policy, 38, 922-935.

Jensen, M. (1993). The modern industrial revolution: Exit, and the failure of internal control systems. Journal of Finance, 48, 831-880.

Jensen, R., \& Thursby, M. (2001). Proofs and prototypes for sale: The licensing of university inventions. American Economic Review, 91(1), 240-259.

Kenney, M., \& Goe, W. R. (2004). The role of social embeddedness in professorial entrepreneurship: a comparison of electrical engineering and computer science at UC Berkeley and Stanford. Research Policy, 33(5), 691-707.

Kerr, S. (1975). On the folly of rewarding A while hoping for B. Academy of Management Journal, 18, 769-783.

Klemm, M., Sanderson, S., \& Luffman, G. (1991). Mission statements: Selling corporate values to employees. Long Range Planning, 24(3), 73-78.

Klofsten, M., \& Jones-Evans, D. (2000). Comparing academic entrepreneurship in Europe - The case of Sweden and Ireland. Small Business Economics, 14(4), 299-309.

Krabel, S., \& Mueller, P. (2009). What drives scientists to start their own company?: An empirical investigation of Max Planck Society scientists. Research Policy, 38(6), 947-956.

Kram, K. E., \& Isabella, L. A. (1985). Mentoring alternatives: The role of peer relationships in career development. Academy of Management Journal, 28, 110-132.

Krueger, N. (1993). Impact of prior entrepreneurial exposure on perceptions of new venture feasibility and desirability. Entrepreneurship Theory and Practice, 18(1), 5-21.

Krueger, N., Reilly, M., \& Carsrud , A. (2000). Competing models of entrepreneurial intentions. Journal of Business Venturing, 15, 411-432. 
Kuenzi, M., \& Schminke, M. (2009). Assembling fragments into a lens: A review critique, and proposed research agenda for the organizational work climate literature. Journal of Management, 35(3), 634-717.

LeBreton, J. M., \& Senter, J. L. (2008). Answers to twenty questions about interrater reliability and interrater agreement. Organizational Research Methods, 11, 815-852.

Lee, L., Wong, P. K., Foo, M. D., \& Leung, A. (2011). Entrepreneurial intentions: The influence of organizational and individual factors. Journal of Business Venturing, 26, 124-136.

Lewis, W., Agarwal, R., \& Sambamurthy, V. (2003). Sources of influence on beliefs about information technology use: An empirical study of knowledge workers. MIS Quarterly, 27(4), 657-678.

Link, A., Siegel, D., \& Bozeman, B. (2006). An empirical analysis of the propensity of academics to engage in informal university technology transfer. Rensselaer Working Papers in Economics, $\mathrm{N}^{\circ} 0610$

Lockett, A., \& Wright, M. (2005). Resources, capabilities, risk capital and the creation of spinout companies. Research Policy, 34(7), 1043-1057.

Louis, K. S., Blumenthal, D., Gluck, M. E., \& Stoto, M. A. (1989). Entrepreneurs in academe : An exploration of behaviors among life scientists. Administrative Science Quarterly, 34(1), 110-131.

Lüthje, C., \& Franke, N. (2003). The 'making' of an entrepreneur: Testing a model of entrepreneurial intent among engineering students at MIT. $R \& D$ management, 33, 135-148.

Mansfield, E. (1998). Academic research and industrial innovation. Research Policy, 26(7-8), 773-776.

Markman, G. D., Gianiodis, P. T., Phan, P. H., \& Balkin, D. B. (2004). Entrepreneurship from the ivory tower: Do incentive systems matter? Journal of Technology Transfer, 29, 353-364.

Markman, G. D., Siegel, D. S., \& Wright, M. (2008). Research and technology commercialization. Journal of Management Studies, 45(8), 1401-1423.

Martin, C. A., \& Bush, A. J. (2000). Do role models influence teenagers' purchase intentions and behavior? Journal of Consumer Marketing, 17(5), 441-453.

Martinelli, A., Meyer, M., \& von Tunzelmann, N. (2008). Becoming an entrepreneurial university? A case study of knowledge exchange relationship and faculty attitudes in a medium-sized, research-oriented university. Journal of Technology Transfer, 33(2), 259-283.

Mosey, S., \& Wright, M. (2007). From human capital to social capital: A longitudinal study of technology-based academic entrepreneurs. Entrepreneurship Theory and Practice, 31(6), 909-935.

Mosey, S., Noke, H., \& Binks, M. (2012). The influence of human and social capital upon the entrepreneurial intentions and destinations of academics. Technology Analysis \& Strategic Management, 24(9), 893-910.

Nanda, R., \& Sorensen, J. (2010). Workplace peers and entrepreneurship. Management Science, 56(7), 1116-1126

O'Shea, R. P., Allen, T. J., Chevalier, A., \& Roche, F. (2005). Entrepreneurial orientation, technology transfer and spinoff performance of U.S. universities. Research Policy, 34(7), 994-1009.

Obschonka, M., Goethner, M., Silbereisen, R., \& Cantner, U. (2012). Social identity and the transition to entrepreneurship: the role of group identification with workplace peers. Journal of Vocational Behavior, 80(1), 137-147.

OECD (2003). Turning science into business: patenting and licensing at public research organizations. Paris: OECD.

Ostroff, C., Kinicki, A. J., \& Tamkins, M. M. (2003). Organizational culture and climate. In W. C. Borman, D. R. Ilgen, \& R. J. Kimoski (Eds.), Handbook of Psychology: Industrial and Organizational Psychology (pp. 565-593). New York: Wiley.

Peng, M., Sun, S., Pinkham, B., \& Chen, H. (2009). The institution-based view as a third leg for a strategy tripod. Academy of Management Perspectives, 23(3), 63-81.

Peters, L. S, \& Fusfeld, H. (1982). University-industry research relationships, National Science Foundation. 
Ping, C. (1980). Industry and the universities: Developing cooperative research relationships in the national interest. Washington DC: National Commission on Research.

Podsakoff, P. M., MacKenzie, S. B., \& Lee, J. Y. (2003). Common method variance in behavioral research: A critical review of the literature and recommended remedies. Journal of Applied Psychology, 88(5), 879-903.

Powers, J. (2003). Commercializing academic research: Resource effects on performance of university technology transfer. The Journal of Higher Education, 74(1), 26-50.

Preacher, K. J., \& Hayes, A. F. (2008). Asymptotic and resampling strategies for assessing and comparing indirect effects in multiple mediator models. Behavior Research Methods, 40(3), 879-891.

Prodan I., \& Drnovsek M. (2010). Conceptualizing academic-entrepreneurial intentions: An empirical test. Technovation, 30, 332-347.

Quinn, R. E., \& Rohrbaugh, J. (1983). A special model of effectiveness criteria: toward a competing values approach to organizational analysis. Management Science, 29, 363-377.

Rasmussen, E., \& Borch, O. J. (2010). University capabilities in facilitating entrepreneurship: A longitudinal study of spin-off ventures at mid-range universities. Research Policy, 39(5), 602612 .

Rasmussen, E., Moen, O., \& Gulbrandsen, M. (2006). Initiatives to promote commercialization of university knowledge. Technovation, 26(4), 518-533.

Reichers, A. E., \& Schneider, B. (1990). Climate and culture: an evolution of constructs. In B. Schneider (Ed.), Organizational climate and culture. San Francisco: Jossey-Bass.

Rhoades, L., Eisenberger, R., \& Armeli, S. (2001). Affective commitment to the organization: The contribution of perceived organizational support. Journal of Applied Psychology, 86(5), 825-836.

Roberts, E. (1991). Entrepreneurs in high technology, lessons from MIT and beyond. Oxford: Oxford University Press.

Rothaermel, F., Agung, S., \& Jiang, L. (2007). University entrepreneurship: A taxonomy of the literature. Industrial and Corporate Change. 16(4), 691-791.

Samsom, K., \& Gurdon, M. (1993). University scientists as entrepreneurs: A special case of technology transfer and high-tech venturing. Technovation, 13(2), 63-71.

Schein, E. H. (2000). Sense and nonsense about culture and climate. In N. M. Ashkanasy, C. P. M. Wilderom, \& M. F. Peterson (Eds.), Handbook of organizational culture and climate. Thousand Oaks, CA: Sage.

Schein, E.H. (1985). Organizational culture and leadership. San Francisco: Jossey-Bass.

Schneider, B., Ehrhart, M. G., \& Macey, W. H. (2013). Organizational climate and culture. Annual Review of Psychology, 64, 361-388.

Schneider, B., White, S. W., \& Paul, M. C. (1998). Linking service climate and customer perceptions of service quality: Test of a causal model. Journal of Applied Psychology, 83(2), 150163 .

Scott, W. R. (1987). The adolescence of institutional theory. Administrative Science Quarterly, $32,493-511$

Scott, W. R. (2001). Institutions and organizations. Thousand Oaks, CA: Sage.

Shalley, C. E., Zhou, J., \& Oldham, G. R. (2004). The effect of personal and contextual characteristics on creativity: Where should we go from here? Journal of Management, 30(6), 933958.

Shane, S. (2000). Prior knowledge and the discovery of entrepreneurial opportunities. Organization Science, 11(4), 448-169.

Shane, S. (2004). Encouraging university entrepreneurship? The effect of the Bayh-Dole act on university patenting in the United States. Journal of Business Venturing, 19(1),127-151.

Siegel, D. S., Veugelers, R., \& Wright, M. (2007). Technology transfer offices and commercialization of university intellectual property: Performance and policy implications Oxford Review of Economic Policy, 23(4), 640-660. 
Siegel, D. S., Waldman, D. A., \& Link, A. N. (2003). Assessing the impact of organizational practices on the relative productivity of university technology transfer offices: An exploratory study. Research Policy, 32(1), 27-48.

Siegel, D. S., Waldman, D. A., Atwater, L. E., \& Link, A. N. (2004). Toward a model of the effective transfer of scientific knowledge from academicians to practitioners: Qualitative evidence from the commercialization of university technologies. Journal of Engineering and Technology Management, 21, 115-142.

Smith, M., Heady, R. B., Carson, P. P., \& Carson, K. D. (2001). Do missions accomplish their missions? An exploratory analysis of mission statement content and organizational longevity. Journal of Applied Management and Entrepreneurship, 6, 75-96

Souitaris, V., Zerbinati, S., \& Al-Laham, A. (2007). Do entrepreneurship programmes raise entrepreneurial intention of science and engineering students? The effect of learning, inspiration and resources. Journal of Business Venturing, 22, 566-592.

Stankiewicz, R. (1986). Academics and entrepreneurs: developing university-industry relations. New York: the New Press.

Stuart, T. E., \& Ding, W. W. (2006). When do scientists become entrepreneurs? The social structural antecedents of commercial activity in the academic life sciences. American Journal of Sociology, 112(1), 97-144.

Swales, J. M., \& Rogers, P. S. (1995). Discourse and the projection of corporate culture -the mission statement. Discourse \& Society, 6(2), 223-242.

Szulanski, G. (1996). Exploring internal stickiness: Impediments to the transfer of best practice within the firm. Strategic Management Journal, 17, 27-43.

Tesluk, P. E., Farr, J. L., \& Klein, S. R. (1997). Influences of organizational culture and climate on individual creativity. Journal of Creative Behavior, 31(1), 27-41.

Thornton, P. H. (1999). The sociology of entrepreneurship. Annual Review of Sociology, 25, 1946.

Tijssen, R. (2006). Universities and industrially relevant science: Towards measurement models and indicators of entrepreneurial orientation. Research Policy, 35(10), 1569-1585.

Tourangeau, R., Rips, L. J., \& Rasinski, K. (2000). The psychology of survey response. Cambridge: Cambridge University Press.

Tyagi, P. K. (1982). Perceived organizational climate and the process of salesperson motivation. Journal of Marketing Research, 19(2), 240-254

Van Looy, B., Landoni, P., Callaert, J., van Pottelsberghe, B., Sapsalis, E., \& Debackere, K. (2011). Entrepreneurial effectiveness of European universities: An empirical assessment of antecedents and trade-offs. Research Policy, 40(4), 553-564.

Walter, S., Parboteeah, K., \& Walter, A. (2011). University departments and self-employment intentions of business students: A cross-level analysis. Entrepreneurship Theory and Practice, $37(2), 175-200$.

West, J. (2008). Commercializing open science: Deep space communications as the lead market for Shannon theory, 1960-73. Journal of Management Studies, 45(8), 1506-1532.

Williams, L.S. (2008). The mission statement. A corporate reporting tool with a past, present and future. Journal of Business Communication, 45(2), 94-119.

Wright, M., Clarysse, B., Lockett, A., \& Knockaert, M. (2008). Mid-range universities' linkages with industry: Knowledge types and the role of intermediaries. Research Policy, 37(8), 12051223

Zilber, T.B. 2012. The relevance of institutional theory for the study of organizational culture. Journal of Management Inquiry, 21, 88-93.

Zhao, H., Seibert, C., \& Hills, C. (2005). The mediating role of self-efficacy in the development of entrepreneurial intentions. Journal of Applied Psychology, 90(2), 1265-1272.

Zohar, D., \& Hofmann, D.H. (2012). Organizational culture and climate. In The Oxford Handbook of Industrial and Organizational Psychology, S.W.J. Kozlowski (ed.). Oxford University Press.

Zucker, L.G. (1987). Institutional patterns and organizations: culture and environment. Mass: Ballinger. 

